DOI

\title{
ОСОБЛИВОСТІ ПСИХОПАТОЛОГІЧНОЇ СИМПТОМАТИКИ У ЕМІГРАНТІВ ТА РЕЕМІГРАНТІВ, ХВОРИХ НА ДЕПРЕСИВНІ РОЗЛАДИ
}

\section{ДВНЗ «Тернопільський державний медичний університет імені І. Я. Горбачевського МОз України»}

\begin{abstract}
РЕЗЮМЕ. Дослідження особливостей психопатологічної симптоматики за допомогою опитувальника Symptom Check List-90-Revised-SCL-90-R дозволило встановити, що середхворихна психогенні депресивні розлади емігрантів (196 осіб) були значуще вищими у порівнянні з реемігрантами (191 особа) та не емігрантами (198 осіб)

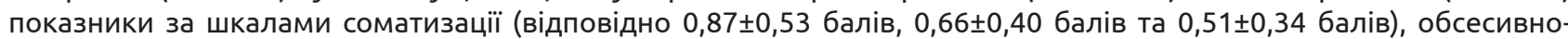
компульсивних розладів $(1,43 \pm 0,77$ балів, $1,13 \pm 0,44$ балів та 0,98 $\pm 0,48$ балів), тривожності $(1,73 \pm 1,07$ балів,

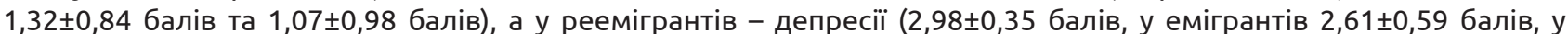

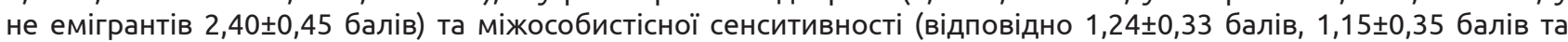

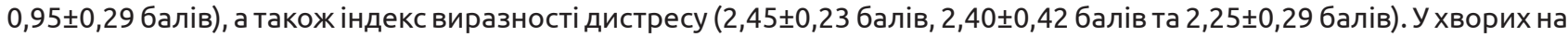
ендогенні депресивні розлади вплив фактора еміграції виявився меншим, однак загальні тенденції зберігаються:

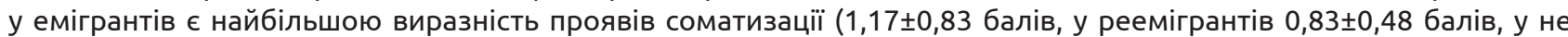

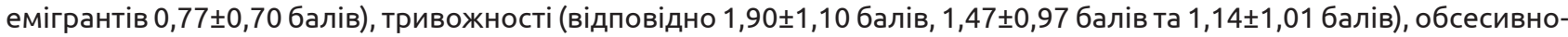

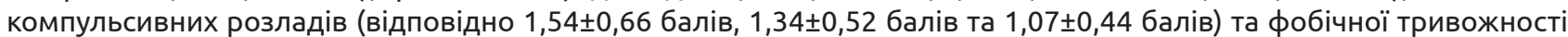

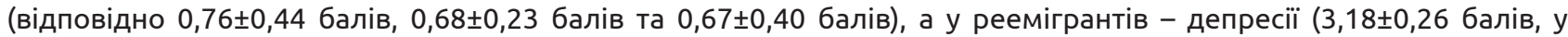

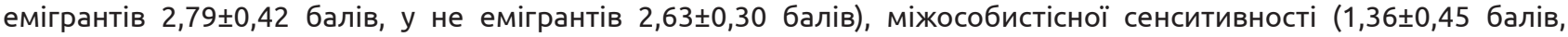

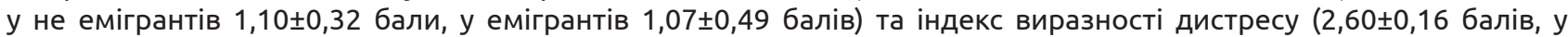

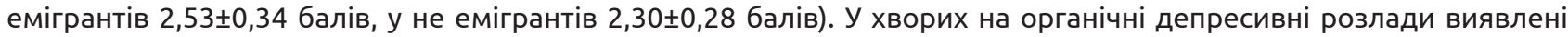
більш складні закономірності, зумовлені характером депресії: значущі розбіжності у показниках між групами

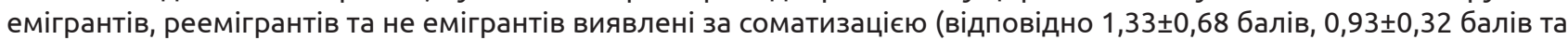

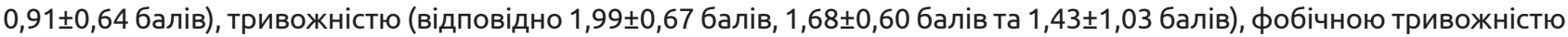

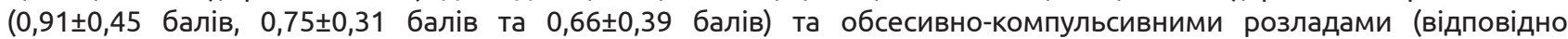

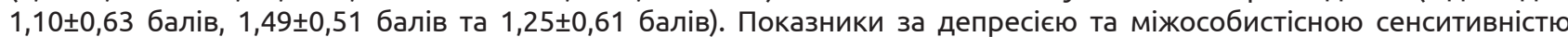

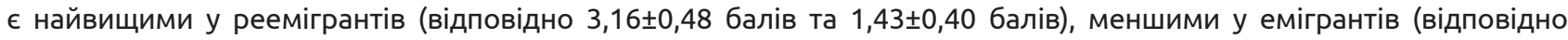

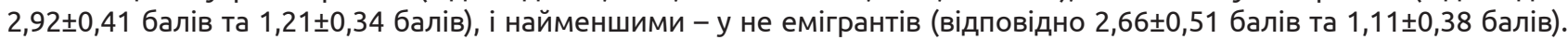
Виявлені закономірності можуть бути пояснені впливом об'єктивних соціально-психологічних факторів.

КЛЮчОВІ СЛОВА: депресивні розлади, емігранти, реемігранти, психопатологічна симптоматика.
\end{abstract}

Вступ. Проблема еміграції та рееміграції в Україні входить до числа найбільш актуальних державних та суспільних проблем. Еміграція $€$ одним з наймасовіших соціальних процесів у світі, який останніми роками виявляє очевидну тенденцію до зростання. За даними Міжнародної організації з міграції, станом на 2011 рік кількість українських емігрантів складає близько 6,5 млн осіб (14,4\% постійного населення) [1]. Уповноважений Верховної Ради України з прав людини (2011) наводить дані щодо близько 7 млн трудових емігрантів-громадян України [2]. При цьому офіційна еміграція складає незначну частину загального обсягу еміграції; переважна більшість мігрантів (від 60 до 90\%) виїжджають за кордон з декларованою метою туризму, відвідування родичів тощо з подальшим працевлаштуванням (легальним або нелегальним) у країнах-реципієн$\operatorname{Tax}[1]$.

Еміграція розглядається як фактор, що провокує маніфестацію або екзацербацію ендогенних психічних захворювань $[3,4,5]$. В структурі особистості емігрантів виявляються емоційна нестійкість, тривожність, соціальна інтроверсія, кон- формність на поведінковому рівні, підозрілість, слабка інтеграція особистісних рис у вигляді емотивності та фрустрованості, низький рівень фрустраційної толерантності. В структурі психічних розладів емігрантів домінують психодезадаптаційні стани, посттравматичний стресовий розлад, неврастенія, пролонгована депресивна реакція та помірний депресивний епізод $[6,7,8,9]$. Водночас, наукові дані щодо структури і поширеності психічних розладів серед емігрантів $\epsilon$ недостатніми і вкрай суперечливими. В Україні, незважаючи на виняткову актуальність проблеми еміграції, взагалі відсутні серйозні наукові дослідження, що спрямовані на вивчення депресивних розладів у емігрантів та реемігрантів.

Мета дослідження - встановити особливості психопатологічної симптоматики у емігрантів та реемігрантів, хворих на депресивні розлади.

Матеріал і методи дослідження. Нами було обстежено за допомогою опитувальника виразності психопатологічної симптоматики Symptom Check List-90-Revised - SCL-90-R [10] 196 осі6, які щонайменше протягом останнього року проживали за межами України і планували найближ- 
Огляди літератури, оригінальні дослідження, погляд на проблему

чим часом повернутися за кордон (емігранти), 191 особа, які не менше року проживали за межами України і протягом останнього року повернулися для постійного проживання в Україну (реемігранти) та 198 осіб, які постійно проживають в Україні і ніколи не виїжджали за ії̈ межі для тривалого проживання (не емігранти). Усім обстеженим був встановлений остаточний клінічний діагноз депресивного розладу відповідно до критеріїв MKX-10. Психогенні депресивні розлади (коди за MKX-10 F43.21 та F43.22) встановлені у 69 не емігрантів, 68 емігрантів та 67 реемігрантів, ендогенні (коди за MKX-10 F31.3, F31.4, F32.1, F32.2, F33.1 та F33.2) - відповідно у 65, 66 та 63 осі6, органічні (код за MKX-10 F06.3) - відповідно у 64, 62 та 61 особи; розбіжності між групами не значущі.

Статистичний аналіз результатів проводився за допомогою непараметричного тесту Манна-Уїтні.

Результати й обговорення. У хворих на психогенні депресивні розлади були виявлені значущі відмінності у виразності психопатологічної симптоматики з урахуванням фактора еміграції (рееміграції). Так, показник за шкалою соматизації, що відображує дистрес внаслідок неприємних соматичних відчуттів (соматовегетативний компонент), $є$ найвищим у емігрантів - 0,87 $\pm 0,53$

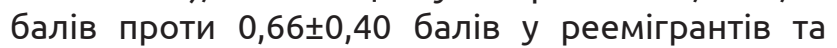

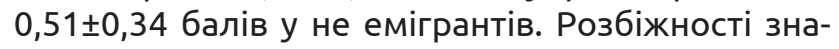
чущі при порівнянні груп не емігрантів та емігрантів $(p<0,01)$, не емігрантів та реемігрантів $(p<0,05)$, емігрантів та реемігрантів $(p<0,05)$. Аналогічні закономірності виявлені при дослідженні виразності обсесивно-компульсивних розладів: найбільш високий показник за цією шкалою у емігрантів

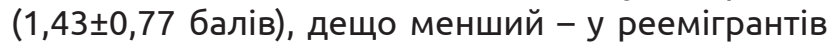
$(1,13 \pm 0,44$ балів), і найменший - у не емігрантів

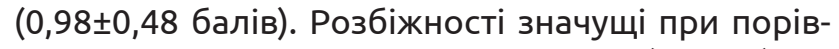
нянні груп не емігрантів та емігрантів $(p<0,01)$, не емігрантів та реемігрантів $(p<0,1)$, емігрантів та реемігрантів $(p<0,05)$. Найбільшою мірою група емігрантів відрізняється за показниками тривожності $(1,73 \pm 1,07$ балів проти 1,32 $\pm 0,84$ балів у рее-

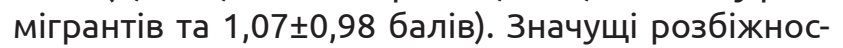
ті виявлені для груп не емігрантів та емігрантів $(p<0,01)$, не емігрантів та реемігрантів $(p<0,05)$ i емігрантів та реемігрантів $(p<0,05)$. Також у емігрантів були виявлені дещо вищі показники за шкалами ворожості (що включає думки, почуття або дії, що є проявами негативного афективного стану злості - агресію, дратівливість, гнів та обурення): 0,72 $\pm 0,92$ балів порівняно з реемігрантами $(0,60 \pm 0,85$ балів) та не емігрантами $(0,57 \pm 0,90$ балів), однак, значущі розбіжності $(p<0,1)$ виявлені лише при порівнянні емігрантів та не емігрантів. Аналогічні закономірності виявлені при аналізі показників фобічної тривожності (стійка реакція страху на певних людей, місця, об'єкти або ситуації, що характеризується як ірраціональна і супроводжується поведінкою уникання): у не емігрантів вони $\epsilon$ найнижчими $(0,61 \pm 0,39$ балів), у реемігрантів - помітно вищими $(0,68 \pm 0,29$ балів), а у емігрантів - найвищими $(0,74 \pm 0,54)$. Натомість, у реемігрантів найбільш вираженими були показники, що характеризують депресивні та астенічні тенденції. Так, показник депресії у цій групі склав

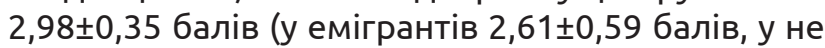

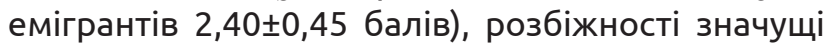
при порівнянні груп не емігрантів та емігрантів $(p<0,05)$, не емігрантів та реемігрантів $(p<0,01)$, і емігрантів та реемігрантів $(p<0,01)$. Показник міжособистісної сенситивності (відчуття власної неадекватності або неповноцінності, особливо у порівнянні себе з іншими) у реемігрантів склав $1,24 \pm 0,33$ балів, що значуще $(p<0,05)$ більше, ніж у емігрантів (1,15 $\pm 0,35$ балів) та не емігрантів $(0,95 \pm 0,29$ балів). Очевидно, що підвищення показників за цими шкалами $є$ відображенням найбільшої виразності фрустраційних тенденцій серед реемігрантів та переживанням власної неповноцінності та неспроможності як під впливом депресивних переживань, так і внаслідок усвідомлення об'єктивних проблем і труднощів.

Показники паранойяльності та психотизму, що $є$ відображенням порушень мислення та проявів психозу, нетипові для депресивних розладів, і у дослідженому контингенті виражені слабко (0,1 - 0,5 балів), без значущих розбіжностей між групами емігрантів та реемігрантів.

Загальний показник за даними опитувальника SLC-90 є найбільшим у емігрантів $(1,25 \pm 0,51$ балів), дещо меншим - у реемігрантів $(1,21 \pm 0,33$ балів), і найнижчим - у не емігрантів $(0,99 \pm 0,38$ балів). Значущі розбіжності виявлені при порівнянні груп не емігрантів та емігрантів $(p<0,01)$, не емігрантів та реемігрантів $(p<0,01)$.

Індекс проявлення симптоматики (кількість пунктів, на які дана позитивна відповідь - від 1 до 4 балів) також $\epsilon$ найвищим у емігрантів -

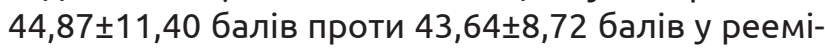
грантів та $38,77 \pm 10,33$ балів у не емігрантів. Значущі розбіжності виявлені при порівнянні груп не емігрантів та емігрантів $(p<0,01)$, не емігрантів та реемігрантів $(p<0,01)$.

Натомість, індекс виразності дистресу є най-

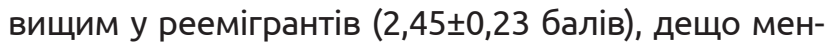

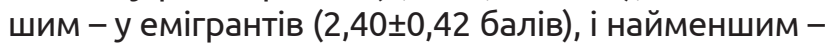

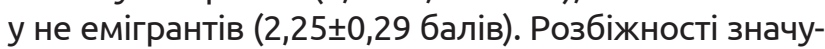
щі при порівнянні груп не емігрантів та емігрантів $(p<0,05)$ та не емігрантів та реемігрантів $(p<0,01)$.

Таким чином, для реемігрантів типовою $\epsilon$ більша виразність депресивних та астено-невро- 
Огляди літератури, оригінальні дослідження, погляд на проблему

тичних проявів, тоді як для емігрантів - тривожних, фобічних та соматизованих розладів.

Для хворих на ендогенні депресивні розлади характерні більш глибокі зміни у афективній сфері і пов'язаних з нею сферах. При цьому особливості психопатологічної симптоматики у них мають як спільні риси з хворими на психогенні депресії, так і певні відмінності. Зокрема, виразність проявів соматизації $\epsilon$ найбільшою у

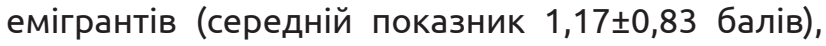
меншою - у реемігрантів $(0,83 \pm 0,48$ балів), і найменшою - у не емігрантів $(0,77 \pm 0,70$ балів). Значущі розбіжності виявлені при порівнянні груп не емігрантів та емігрантів ( $p<0,01)$, не емігрантів та реемігрантів ( $<<0,05)$, емігрантів та реемігрантів $(p<0,05)$. Аналогічні закономірності виявлені для розладів тривожного спектра: тривожності (по-

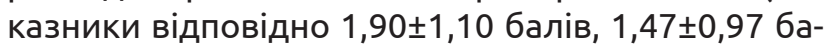

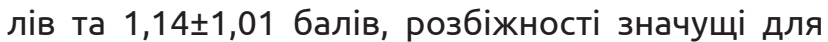
груп не емігрантів та емігрантів $(p<0,01)$, не емігрантів та реемігрантів ( $<<0,05)$, емігрантів та реемігрантів ( $p<0,05)$, обсесивно-компульсивних роз-

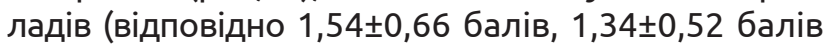

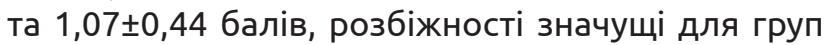
не емігрантів та емігрантів ( $p<0,01)$, не емігрантів та реемігрантів $(p<0,01)$, емігрантів та реемігрантів $(p<0,1)$, та фобічної тривожності (відповідно

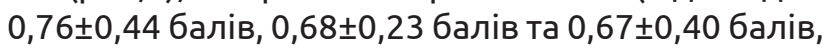
розбіжності значущі при порівнянні не емігрантів та емігрантів $(p<0,1)$, не емігрантів та реемігрантів $(p<0,05)$. Показник ворожості незначно більшим $\epsilon$ не емігрантів, ніж у емігрантів (відповідно

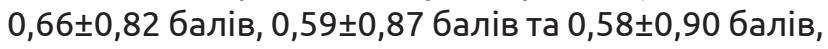
однак розбіжності між групами, на відміну від психогенної депресії, $\epsilon$ незначущими. Також не значущими є розбіжності за показниками психотизму та паранойяльних симптомів. Щодо проявів депресії, то вони є найбільш вираженими у реемігрантів $(3,18 \pm 0,26$ балів), дещо меншими - у емігрантів $(2,79 \pm 0,42$ балів) і найменшими - у не

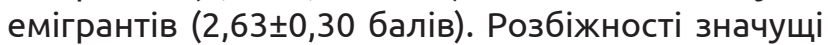
при порівнянні між собою усіх груп (p<0,01). Показник міжособистісної сенситивності також $є$ най-

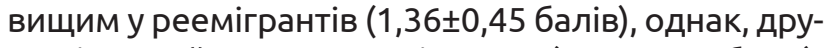

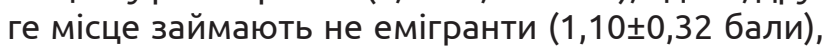
і найнижчий показник виявлений у емігрантів $(1,07 \pm 0,49$ балів). Значущі розбіжності виявлені при порівнянні груп не емігрантів та реемігрантів $(p<0,01)$ та емігрантів та реемігрантів $(p<0,01)$. Таким чином, прояви міжособистісної сенситивності (у хворих на депресивні розлади вона проявляється насамперед відчуттям власної неповноцінності та неспроможності) у емігрантів $\epsilon$ найменш вираженими, що, на наш погляд, $є$ відображенням специфічного соціального-психологічного статусу емігрантів, які мають більші можливос- ті для заробітку і позбавлені ряду актуальних проблем, притаманних сучасному українському суспільству. Реемігрантам, які з тих чи інших причин не змогли реалізувати себе під час роботи за кордоном, і змушені повернутися на батьківщину, притаманна найгірша самооцінка і найвищі рівні міжособистісної сенситивності, що також, на наш погляд, $є$ адекватним наслідком психологічної переробки ситуації депривації, необхідності адаптуватися до складних реалій та фрустраційних проявів.

Інтегральний показник серед хворих на ендогенні депресивні розлади є найбільшим у емі-

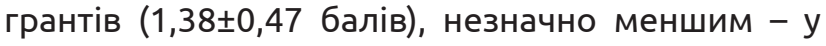

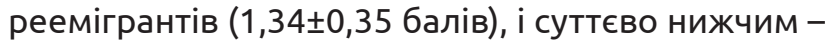
у не емігрантів $(0,77 \pm 0,70$ балів). Значущі розбіжності виявлені при порівнянні груп не емігрантів та емігрантів ( $p<0,01)$, не емігрантів та реемігрантів $(p<0,01)$.

Аналогічно, найвищий індекспроявлення симп-

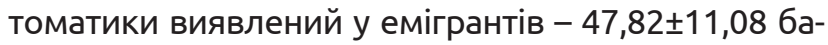

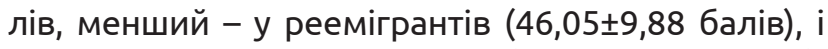

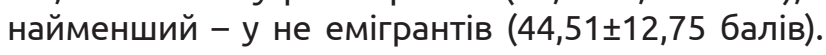
Розбіжності виявлені лише при порівнянні груп не емігрантів та емігрантів $(p<0,1)$.

Індекс виразності дистресу $\epsilon$ найвищим у

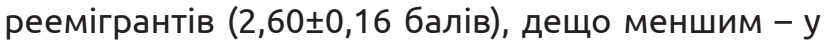
емігрантів $(2,53 \pm 0,34$ балів), і найнижчим - у не

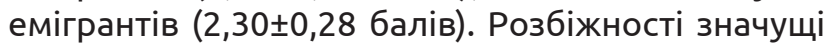
при порівнянні груп не емігрантів та емігрантів $(p<0,01)$ та не емігрантів та реемігрантів $(p<0,01)$.

Депресивні розлади органічного ґенезу $\epsilon$ більш ригідними у плані психопатологічної симптоматики. Однак фактор еміграції (рееміграції) справляє певний вплив на особливості психопатологічних проявів і у цій групі хворих. Так, значущі розбіжності у показниках між усіма групами (емігрантів, реемігрантів та не емігрантів) були ви-

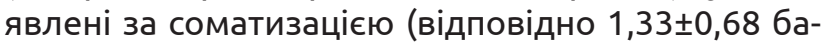

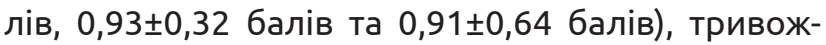

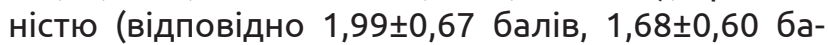
лів та $1,43 \pm 1,03$ балів), фобічною тривожністю

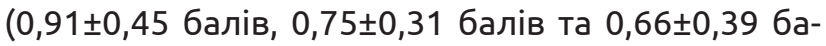
лів). Для усіх цих шкал найвищі показники виявляються у емігрантів, найнижчі - у не емігрантів, а реемігрантів займають проміжне положення. Натомість, показники за депресією та міжособистісною сенситивністю $є$ найвищими у реемігран-

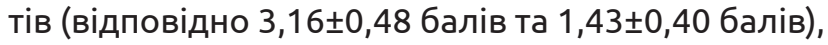
меншими у емігрантів (відповідно 2,92 00,41 балів

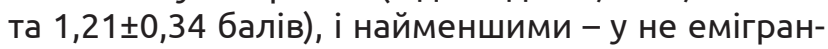

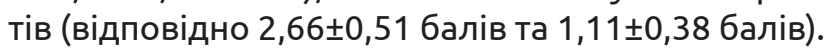
Значущі розбіжності між групами не емігрантів та емігрантів, емігрантів та реемігрантів виявлені такою за обсесивно-компульсивними розлада-

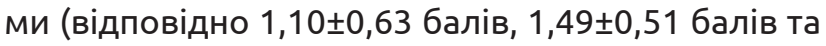


Огляди літератури, оригінальні дослідження, погляд на проблему

$1,25 \pm 0,61$ балів). За рештою показників значущих розбіжностей не виявлено.

Інтегральний показник значуще $(p<0,01)$ відрізняється у групах не емігрантів $(1,22 \pm 0,40$ балів) та емігрантів $(1,47 \pm 0,36$ балів), а також не емігрантів та реемігрантів $(1,40 \pm 0,30$ балів), як і індекс проявлення симптоматики $(44,72 \pm 10,91$ балів,

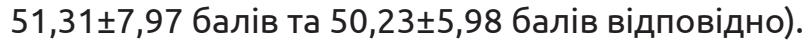

Індекс виразності дистресу $\epsilon$ значуще вищим у емігрантів $(2,55 \pm 0,27$ балів) у порівнянні $з$ не емігрантами $(2,42 \pm 0,32, \mathrm{p}<0,05)$.

Висновки. Виявлені нами особливості психопатологічної симптоматики у емігрантів та реемігрантів, хворих на депресивні розлади різного ґенезу, свідчать про вплив фактору еміграції та рееміграції на психоемоційну сферу хворих на різні види депресії. Найбільше вплив фактору еміграції виявляється у хворих на психогенні депресивні розлади, меншою мірою - у хворих на ендогенні та органічні депресії. В цілому у емігрантів реемігрантів виявлено значуще більш виражені ознаки соматизації, обсесивно-компульсивних розладів і тривожності, дещо вищі - ворожості та фобічної тривожності. У реемігрантів найбільш вираженими були показники, що характеризують депресивні та астенічні тенденції: депресії та міжособистісної сенситивності, а також індекс виразності дистресу. Причинами цих відмінностей, на наш погляд, $\epsilon$ вплив об'єктивного фактору фрустрації у групі реемігрантів та тривожних побоювань щодо можливості продовження роботи за кордоном у зв'язку із психічним захворюванням - у емігрантів.

Перспективи подальших досліджень. Основні перспективи подальших досліджень, на наш погляд, полягають у розробці диференційованих лікувально-реабілітаційних та профілактичних заходів щодо депресивних розладів у емігрантів та реемігрантів з урахуванням виявлених особливостей.

\section{ЛІТЕРАТУРА}

1. Міграція в Україні: факти і цифри / Міжнародна організація з міграції. - Київ: Представництво МОМ в Україні. - 2011.- 7 с.

2. Щорічна Доповідь про стан дотримання та захисту прав і свобод людини в Україні Уповноваженого Верховної Ради України з прав людини: Постанова Верховної Ради України від 05.04.2011 року № 3194-VI // Голос України. - 2011, № 35. - с. 23-29.

3. Incidence of psychotic disorders in immigrant groups to the Netherlands / J. P. Selten, N. Veen, W. Feller [et al.] // British Journal of Psychiatry. - 2001, № 178. P. 67-372.

4. The mental health of migrants / B. E. Gavin, B. D. Kelly, A. Lane [et al.] // Irish Medical Journal. - 2001. - Vol. 94. P. 229-230.

5. Lauber C. Patterns of Psychiatric Inpatient Care in Migrants: Results from Switzerland / C. Lauber, B. Lay, W. Rossler // Swiss Medical Weekly. - 2006, № 135. - P. 50-56.

6. Хармз В. А. Медико-психологические аспекты нарушения психической адаптации эмигрантов: дис... канд. психол. наук: 19.00.04 / Вахид Аблахад Хармз;

Санкт-Петербургский гос. университет, СПб, 2000. $186 \mathrm{c}$.

7. Иванова М. В. Психическое здоровье мигрантов (клинический, социально-психологический и реабилитационный аспекты): дис... канд. мед. наук: 14.01.18 / Марина Владимировна Иванова; НИИ психического здоровья СО РАМН. - Томск, 2007. - 205 с.

8. Колянов В.Б. Некоторые особенности психологической адаптации мигрантов [Електронний ресурс] / В.Б. Колянова, В.П. Боряк, Н.В. Барнаш, Л.В. Михайленко // Режим доступу: http://migrocenter.ru/publ/konfer/ kavkaz/m_kavkaz030.php.

9. Кириленко Я. Интердисциплинарные аспекты миграции [Електронний ресурс] / Я. Кириленко, Е. Чуманская // Архів Національної бібліотеки ім. В. Вернадського. - 2011. - т. 15, № 2 (55), с. 52 - 53. Режим доступу: http://archive.nbuv.gov.ua/portal/chem_biol/Tzhp/ 2011_2/pdf/52-53.pdf.

10. Тарабрина Н. В. Практикум по психологии посттравматического стресса / Н. В. Тарабрина. - СПб. : Питер. - 2001. - C. 146-181.

\section{FEATURES OF PSYCHOPATHOLOGY IN EMIGRANTS AND RE-EMIGRANTS WITH DEPRESSIVE DISORDERS}

@O. P. Venher

\section{Horbachevsky Ternopil State Medical University}

SUMMARY. Studies of psychopathology with help of Symptom Check List-90-Revised-SCL-90-R revealed that among patients with psychogenic depressive disorder immigrants were significantly higher compared to re-emigrants and not immigrants indicators on scales somatization (respectively $0.87 \pm 0.53$ points, $0.66 \pm 0.40$ points and $0.51 \pm 0.34$ points), obsessive-compulsive disorder ( $1.43 \pm 0.77$ points, $1.13 \pm 0.44$ points and $0.98 \pm 0.48$ points), anxiety (1.73 \pm 1.07 points, $1.32 \pm 0.84$ points and $1.07 \pm 0.98$ points), and the re-emigrants - depression (2.98 \pm 0.35 points of emigrants $2.61 \pm 0.59$ points, not immigrants in $2.40 \pm 0.45$ points) and interpersonal sensitivity (respectively $1.24 \pm 0.33$ points, $1.15 \pm 0.35$ points and $0.95 \pm 0.29$ points), and the severity of distress index $(2.45 \pm 0.23$ points, $2.40 \pm 0.42$ points and 
Огляди літератури, оригінальні дослідження, погляд на проблему

$2.25 \pm 0.29$ points). In patients with endogenous depressive disorders impact factor of emigration was lower, but the overall trends remain: the immigrants had the most expressive manifestations of somatization $(1.17 \pm 0.83$ points in re-emigrants $0.83 \pm 0.48$ points in immigrants not $0.77 \pm 0.70$ points), anxiety (respectively $1.90 \pm 1.10$ points, $1.47 \pm 0.97$ points and $1.14 \pm 1.01$ points), obsessive-compulsive disorder (respectively $1.54 \pm 0,66$ points, $1.34 \pm 0.52$ points and $1.07 \pm 0.44$ points), and phobic anxiety (respectively $0.76 \pm 0.44$ points, $0.68 \pm 0.23$ and $0.67 \pm$ points 0.40 points), and the re-emigrants - depression (3.18 \pm 0.26 points in emigrants $2.79 \pm 0.42$ points, not immigrants in $2.63 \pm 0.30$ points), interpersonal sensitivity ( $1.36 \pm 0.45$ points, not immigrants in $1.10 \pm 0.32$ points in emigrants $1.07 \pm 0.49$ points) distress and severity index ( $2.60 \pm 0.16$ points to $2.53 \pm$ immigrants 0.34 points, not immigrants in $2.30 \pm 0.28$ points). In patients with organic depressive disorder revealed more complex patterns due to the nature of depression, significant differences between the groups in terms of immigrants, not emigrants and re-emigrants found for somatization (respectively $1.33 \pm 0.68$ points, $0.93 \pm 0.32$ points and $0.91 \pm 0.64$ points), anxiety (respectively $1.99 \pm 0.67$ points, $1.68 \pm 0.60$ points and $1.43 \pm 1.03$ points), phobic anxiety ( $0.91 \pm 0.45$ points, $0.75 \pm 0.31$ points and $0.66 \pm 0.39$ points) and obsessivecompulsive disorder (respectively $1.10 \pm 0.63$ points, $1.49 \pm 0.51$ and $1.25 \pm$ points 0.61 points). Indicators for depression and interpersonal sensitivity are the highest in the re-emigrants (respectively $3.16 \pm 0.48$ points and $1.43 \pm 0.40$ points) lower in immigrants (respectively $2.92 \pm 0.41$ points and $1.21 \pm 0.34$ points), and the least - in no immigrants (respectively $2.66 \pm 0.51$ points and $1.11 \pm 0.38$ points). Identified patterns can be explained by the influence of objective social and psychological circumstances.

KEY WORDS: depressive disorders, immigrants, re-emigrants, psychotic symptoms. 